\title{
COST SAVING STRATEGY FOR POST OFFICE
}

\section{Silvia Dutková ${ }^{1}$}

\begin{abstract}
The paper displays a system optimization strategy that leads to cost savings for a particular post office. It involves the queuing theory used as a tool to optimize system of incoming customers passing through service areas in order to satisfy their need Using characteristics of the system, it is possible to determine the number of service compartments that are serving during the opening time so that the system is able to manage a number of incoming customers while waiting time remains acceptable for customers. The cost savings from optimizing the number of service compartments mainly relate to the wages of post office employees. By optimizing the number of working compartments according to the intensity of arriving customers, the study depicts the number of compartments needed to fulfill customer service at given time interval. Using this method, a manager can also optimize the working schedule of the employees operating in the post office compartments. The aim of this paper is to analyze the queuing system of the Bytca post office in Slovak and useknowledge from the analysis to optimize the number of compartments and thus reduce the operating costs of the post office.
\end{abstract}

JEL Classification Numbers: C61, L87; DOI: http://dx.doi.org/10.12955/cbup.v6.1137

Keywords: cost savings, queuing theory, optimization, service time, incoming customers

\section{Introduction}

At a time of high-competition growth, it is important for every business owner to consider cost reduction along with future growth and sales. Cost reduction becomes a significant approach for improving financial outcomes and gaining a competitive advantage. The queuing theory is a mathematical discipline that allows one to create a queuing system model, analyze the system's characteristics, and then optimize it accordingly (Husek \& Lauber, 1987). The optimization leads to increased efficiency and cost savings within the system. The queuing system at a post office is a stochastic one with an infinite front, a certain average time frame of service and a number of customer arrivals, and a certain number of service compartments. The system modeling starts with choosing specific post office, measuring and determining the basic parameters of its system, investigating random system variables and then selecting a suitable model, as defined in the queuing theory. The optimization involves simulating changes in the system's parameters and observing the differences in the system's characteristics. It allows one to stabilize the system's parameters and detect critical points within the system. The number of operating service compartments at a particular time is closely related to the number of employees of a post office and their work schedule. By optimizing the number of service compartments based on the inflow of customers and other system parameters, a manager can organize a work schedule according to the actual capacity of the system. This approach of rescheduling employee work times leads to increased efficiency and reduced costs.

\section{Literature Review}

The queuing theory belongs to the applied mathematics category that examines the operation of systems with one or more service lines that enter nodes for servicing input units such as customers and requests (Yang \& Yang, 2014). The goal of queuing theory is to analyze and optimize the system. The analysis involves calculating system metrics such as average queue length, average customer time in the system and line load. The queuing theory is common in many fields, for example, in banks, shops, at petrol stations and post offices (Krpan et al., 2017). This theory was first dignified as a way of solving problems by Erlang at the start of the 20th century in his attempt to reduce service time of phone calls (Hu et al., 2018). Others contributing to developing the queuing theory included Chincin, Kolmogorov and Palm (Hu et al., 2018). Kendall proposed describing queuing models using three factors of a, b, and c in 1953. The first letter (a) specifies the arrival time distribution and the second (b) the service time distribution, wthile the third letter (c) is the number of service lines (Knessl \& van Leeuwaarden, 2015).

According to Marčanić et al. (2015) and Pesko (2015), the queuing model is defined by the following parameters:

\footnotetext{
${ }^{1}$ University of Zilina, Faculty of Operation and Economics of Transport and Communications, Zilina, silvia.dutkova@fpedas.uniza.sk
} 
- Unit input is one of the most important parameters of the system and is a random variable. Time differences between the inputs that represent customers or requirements are random variables and, mostly, in these queuing systems fit to exponential distribution;

- Service time may be a random variable or a constant value. If the service time is a random variable, the service time of a particular customer does not depend on a previous service time and usually, similar to time differences between customer arrivals, it fits an exponential distribution;

- Network of service lines that can have a different number of lines, and lines can work parallel or in sequence;

- Service discipline associated with the order in which customers enter the system. There are disciplines as FIFO that means first in first out, LIFO means last in first out or random order;

- Specific features of the system include random variables that are specific to a particular system such as a limited number of places in a queue, customer preferences, and the ability to change place in the queue.

In some systems, it is not possible to create a queue and if the lines are occupied, the customer is rejected. In other systems, the final number of places in the queue and the wait time are defined. Systems, where the customer can be rejected, are called systems with infinite queue capacity (Achimsky, 1990). The queuing system of a post office can be considered a system with infinite queue capacity and parallel service lines (Fabus \& Krememová, 2013).

If all service compartments are occupied at a certain time, customers are waiting in a queue that can be theoretically defined as infinite. Such a system best corresponds to the Markov system with an infinite front (M, M. n, and $\infty$ (Achimsky, 1988). Such system designation defines an exponential distribution of customer arrival (M), an exponential service time distribution (M), a number of parallel service lines (n), and infinite queue capacity (Liao \& Chiang, 2013).

The system can reach an infinite number of states, $S=\{0,1,2, \ldots, n, \ldots\}$. To stabilize the system, the system stabilization condition,

$$
\rho=\frac{\lambda}{n \mu}<1
$$

must be applied.

where

$\lambda$ is the input parameter and

$n \mu$ is the output intensity.

If the system fulfills the condition of stabilization, it is possible to calculate the system characteristics. The probability of rejection in this type of system is null. According to Brezavscek and Baggia (2014), the average number of served customers in the system is given by the formula:

$$
E(S)=\lambda \frac{1}{\mu}
$$

the average number of customers waiting in the queue is given by the formula:

where

$$
E(L)=\sum_{l=1}^{\infty} l p_{n+l} \text {; }
$$

1 is the service line and

$p$ is probability of customers waiting

the average number of customers in the system is given by the formula:

$$
E(K)=E(S)+E(L)
$$

Accorfing to Bhodori et al. (2014) the average time in the queue is given by the formula:

where

$$
E(W)=\frac{E(L)}{\lambda} .
$$


$\mathrm{E}(\mathrm{W})$ is the average number of customers waiting in the queue divided by the input variable $(\lambda)$ and

$\mathrm{R}$ is the use of the system is given by the formula:

$$
R=\frac{\lambda}{\mathrm{n} \mu} \text {. }
$$

There are many extensive use possibilities of queuing theory. In railway transport, there are problems of designing stations and railways (Achimsky, 1988). In road transport, the queuing theory models can be used to design controlled crossing, road, and service systems (Reiner et al., 2016). Recently, service models have become increasingly used in computer technology, for example, when designing computer networks and monitoring their operation (Peško, 2015).

\section{Data and Methodology}

The main aim of this study was to reduce the cost of operating the Bytca post office in Slovak. Currently, Bytca has about 11000 inhabitants. Several sub-goals were set to achieve this main goal and a detailed analysis examined random variables of the system. To determine the customer input, seven independent measurements of the time interval between customer arrivals were taken directly at the Bytca post office with sample size of 2228 customers. Measurements were taken with a stopwatch at various times during the opening hours of the post office. These data (time intervals between customer arrivals) were grouped to class intervals (minute) as shown in the Table 1 and then tested using a Chi-Square goodness of fit for theoretical probability distribution. The null hypothesis that the measured data would fit an exponential distribution was adopted as true. After the exponential distribution was established, the average number of incoming customers per minute was calculated as:

$$
\lambda=1,30 \text { customer / minute. }
$$

Table 1:Results of measuring time differences between customer arrivals (minutes)

\begin{tabular}{|l|c|c|c|c|c|c|}
\hline Class i & $\begin{array}{c}\text { Class } \\
\text { interval }\end{array}$ & $\begin{array}{c}\text { Central } \\
\text { value }\end{array}$ & $\begin{array}{c}\text { Absolute } \\
\text { frequency }\end{array}$ & $\begin{array}{c}\text { Relative } \\
\text { frequency in } \\
\%\end{array}$ & $\begin{array}{c}\text { Cumulative } \\
\text { absolute } \\
\text { frequency }\end{array}$ & $\begin{array}{c}\text { Cumulative relative } \\
\text { frequency in \% }\end{array}$ \\
\hline $\mathbf{1}$ & $(0 ; 0,5>$ & 0,25 & 1100 & 49 & 1100 & 49 \\
\hline $\mathbf{2}$ & 0,$5 ; 1>$ & 0,75 & 558 & 25 & 1658 & 74 \\
\hline $\mathbf{3}$ & $(1 ; 1,5>$ & 1,25 & 267 & 12 & 1925 & 86 \\
\hline $\mathbf{5}$ & $(1,5 ; 2>$ & 1,75 & 134 & 6 & 2059 & 92 \\
\hline $\mathbf{6}$ & $(2 ; 2,5>$ & 2,25 & 87 & 4 & 2146 & 96 \\
\hline $\mathbf{7}$ & $(2,5 ; 3>$ & 2,75 & 44 & 2 & 2190 & 98 \\
\hline $\mathbf{8}$ & $(3 ; 3,5>$ & 3,25 & 26 & 1 & 2216 & 99 \\
\hline $\mathbf{5}$ & $(3,5, \infty>$ & 3,75 & 12 & 1 & 2228 & 100 \\
\hline
\end{tabular}

Source: Author

Customer service times were treated in the same manner, with sample size was 700 customers. The probability distribution of these data was similarly the exponential distribution. Table 2 displays the measured service times grouped by time intervals (minutes). From this the average customer service time was calculated as:

$$
\frac{1}{\mu}=3,23 \text { minutes. }
$$

\begin{tabular}{|c|c|c|c|c|c|c|}
\hline Class i & $\begin{array}{c}\text { Class } \\
\text { interval }\end{array}$ & $\begin{array}{c}\text { Central } \\
\text { value }\end{array}$ & $\begin{array}{l}\text { Absolute } \\
\text { frequency }\end{array}$ & $\begin{array}{c}\text { Relative } \\
\text { frequency in } \%\end{array}$ & $\begin{array}{c}\text { Cumulative } \\
\text { absolute } \\
\text { frequency }\end{array}$ & $\begin{array}{c}\text { Cumulative } \\
\text { relative frequency } \\
\text { in } \%\end{array}$ \\
\hline 1 & $(0,2>$ & 1 & 301 & 43 & 301 & 43 \\
\hline 2 & $(2,4>$ & 3 & 184 & 26 & 485 & 69 \\
\hline 3 & $(4,6>$ & 5 & 98 & 14 & 583 & 83 \\
\hline 4 & $(6,8>$ & 7 & 59 & 8 & 642 & 92 \\
\hline 5 & $(8,10>$ & 9 & 36 & 5 & 678 & 97 \\
\hline 6 & $(10, \infty>$ & 11 & 22 & 3 & 700 & 100 \\
\hline
\end{tabular}

Table 2: Results of measuring service times (minutes) 


\section{Results and Discussion}

According to the Kendall (Kendall,1953), the queuing system of the Bytca post office is classified as a system with an infinite front, exponential distribution of time intervals between customers, exponential distribution of service time, six parallel service compartments, and a FIFO queue mode. The system is stabilized when it enters only as many customers as it is capable of serving, with stabilization given by the following relationship:

$$
\rho=\frac{\lambda}{\mathrm{n} \mu}<1
$$

In fitting the input parameters of the system, the system meets the stabilization condition:

$$
\begin{gathered}
\rho=\frac{4,20}{6}<1 \\
\rho=0,7<1
\end{gathered}
$$

A consultation with the post office manager revealed six service compartments were available for the entire opening hours of the post office at the time of this study. As the intensity of customer input changes over time, it would be an advantage to have a flexible number of service compartments during post office opening time. Thus, in the resulting model, the opening time is split into individual time

\begin{tabular}{|c|c|c|c|c|c|c|}
\hline Opening hours & 8:00 -9:00 & 9:00-11:00 & 11:00 -13:00 & 13:00 -14:00 & 14:00 -16:00 & $16: 00-17: 00$ \\
\hline $\begin{array}{l}\lambda[\text { cust./min] } \\
\text { average customer } \\
\text { inflow }\end{array}$ & 1,19 & 1,34 & 1,12 & 1,31 & 1,55 & 0,87 \\
\hline $\begin{array}{l}\mu[\mathrm{min}] \text { average } \\
\text { service time }\end{array}$ & 3,23 & 3,23 & 3,23 & 3,23 & 3,23 & 3,23 \\
\hline $\begin{array}{l}\mathrm{E}(\mathrm{S}) \text { the average } \\
\text { number of served } \\
\text { customers }\end{array}$ & 3,84 & 4,33 & 3,62 & 4,23 & 5,01 & 2,81 \\
\hline $\begin{array}{l}\mathrm{E}(\mathrm{L}) \text { the average } \\
\text { number of } \\
\text { customers waiting } \\
\text { in the queue }\end{array}$ & 0,44 & 0,96 & 0,3 & 0,82 & 2,97 & 0,06 \\
\hline $\begin{array}{l}\mathrm{E}(\mathrm{K}) \text { the average } \\
\text { number of } \\
\text { customers in the } \\
\text { system }\end{array}$ & 4,28 & 5,29 & 3,92 & 5,05 & 7,98 & 2,87 \\
\hline $\begin{array}{l}\mathrm{E}(\mathrm{W}) \text { the average } \\
\text { time in the queue }\end{array}$ & 0,37 & 0,72 & 0,27 & 0,63 & 1,92 & 0,07 \\
\hline $\begin{array}{l}\mathrm{R}[\%] \text { use of the } \\
\text { system }\end{array}$ & 64 & 72 & 60 & 71 & 83 & 47 \\
\hline
\end{tabular}
intervals according to customer inflow. Table 3 shows the calculated system characteristics at the time of the study, i.e., with six service compartments for all hourly time frames.

The system characteristic $R$ represents the use utilization of system as a percentage. The system can be theoretically used $100 \%$ of its capacity meaning it is not empty at any point in time. This situation is impossible in practical terms. In the stochastic system, like the queuing system of a post office, at situation of a $100 \%$ use does not exist but this characteristic can be used to indicate how the system would operate with a given number of compartments. Table 3 shows the characteristics reached customer friendly values and the system use $R(\%)$ was $>70 \%$ for almost all hourly timeframes. Thus several simulation scenarios were run with the number of compartments set to achieve a higher system use while at the same time avoiding system overloading. Table 4 shows the system characteristics after optimizing the number of service compartments. 


\begin{tabular}{|c|c|c|c|c|c|c|}
\hline $\begin{array}{l}\text { Opening hours of post } \\
\text { office }\end{array}$ & $\begin{array}{l}8: 00- \\
9: 00\end{array}$ & $\begin{array}{l}9: 00- \\
11: 00\end{array}$ & $\begin{array}{l}11: 00- \\
13: 00\end{array}$ & $\begin{array}{c}13: 00- \\
14: 00\end{array}$ & $\begin{array}{c}14: 00- \\
16: 00\end{array}$ & $\begin{array}{l}16: 00- \\
17: 00\end{array}$ \\
\hline Number of compartments & 5 & 5 & 5 & 5 & 6 & 4 \\
\hline $\begin{array}{l}\lambda[\text { cust./min] average } \\
\text { customer inflow }\end{array}$ & 1,19 & 1,34 & 1,12 & 1,31 & 1,55 & 0,87 \\
\hline $\begin{array}{l}\mu[\mathrm{min}] \text { average service } \\
\text { time }\end{array}$ & 3,23 & 3,23 & 3,23 & 3,23 & 3,23 & 3,23 \\
\hline $\begin{array}{l}\mathrm{E}(\mathrm{S}) \text { the average number } \\
\text { of served customers }\end{array}$ & 3,84 & 4,2 & 3,62 & 4,23 & 5,02 & 2,82 \\
\hline $\begin{array}{l}\mathrm{E}(\mathrm{L}) \text { the average number } \\
\text { of customers waiting in the } \\
\text { queue }\end{array}$ & 1,66 & 3,63 & 1,47 & 4,08 & 4,28 & 1,08 \\
\hline $\begin{array}{l}\mathrm{E}(\mathrm{K}) \text { the average number } \\
\text { of customers in the system }\end{array}$ & 5,5 & 7,82 & 10,46 & 8,31 & 9,3 & 3,9 \\
\hline $\begin{array}{l}\mathrm{E}(\mathrm{W}) \text { the average time in } \\
\text { the queue }\end{array}$ & 1,4 & 2,79 & 0,42 & 3,12 & 2,76 & 1,24 \\
\hline $\mathrm{R}[\%]$ use of the system & 77 & 84 & 72 & 85 & 84 & 71 \\
\hline
\end{tabular}

Along with optimizing the service compartments, the working schedule of service compartments employees was modified (Figure 1). Figure 1 shows a one-day work schedule of nine service compartment employee with three employees working in two compartments for morning, afternoon, and all-day shifts.

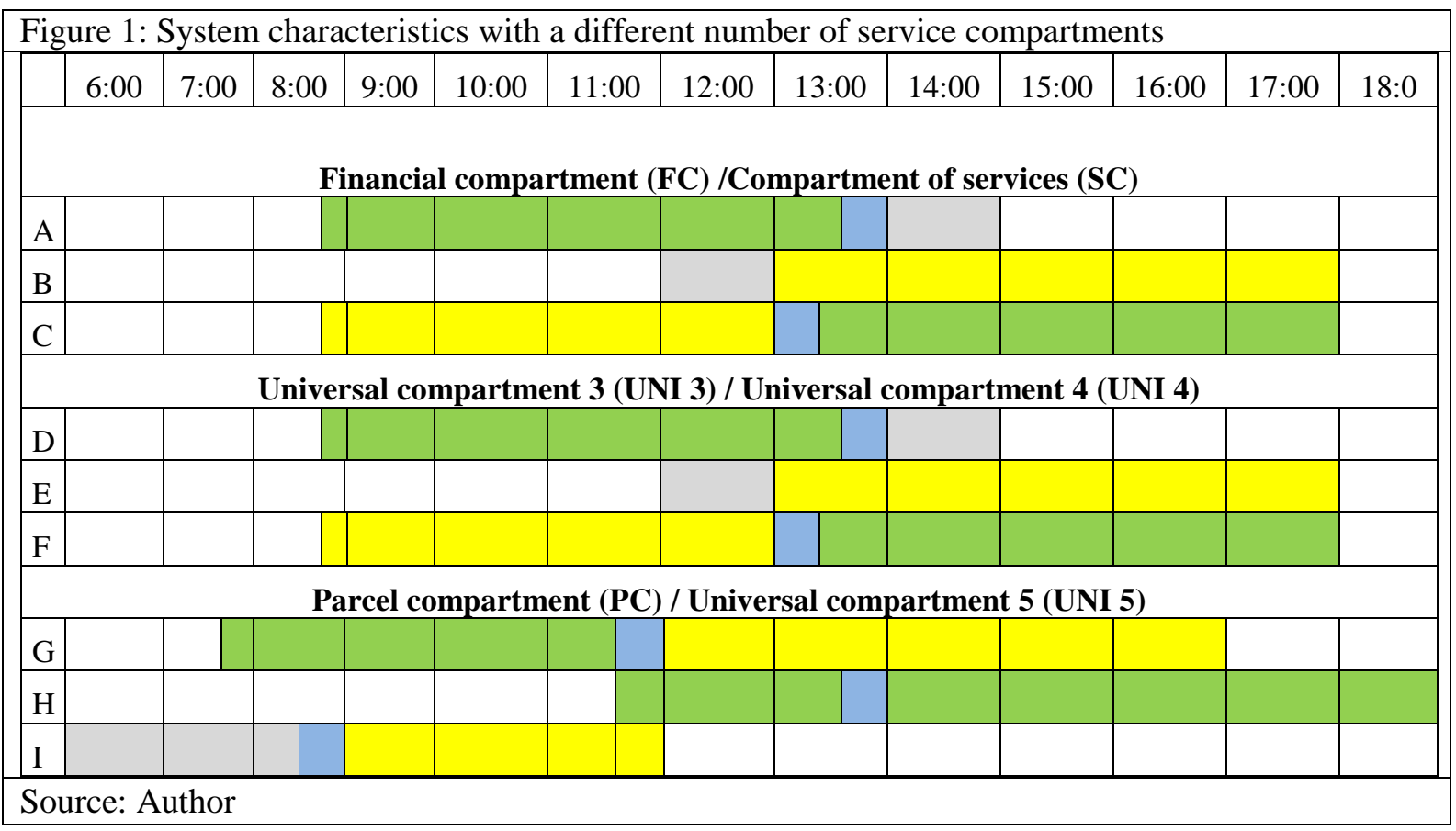

In this simulate scenario, all six compartments serve only at the hourly time frames 14:00 to 15:00 and 15:00 to 16:00 and therefore only two employees are needed to work in the compartments. In a modified work schedule, employees are scheduled to serve universal compartments 3 and 4 (UNI 3 and UNI 4), and thus ensure coverage of the entire product portfolio of the post office. The service (SC) and financial compartments (FC) provide services that are not provided by the universal compartments. The parcel compartment (PC) must stay open for the entire post office opening hours. Figure 2 shows a modified work schedule for the employees, D and E shown in Figure 1. 


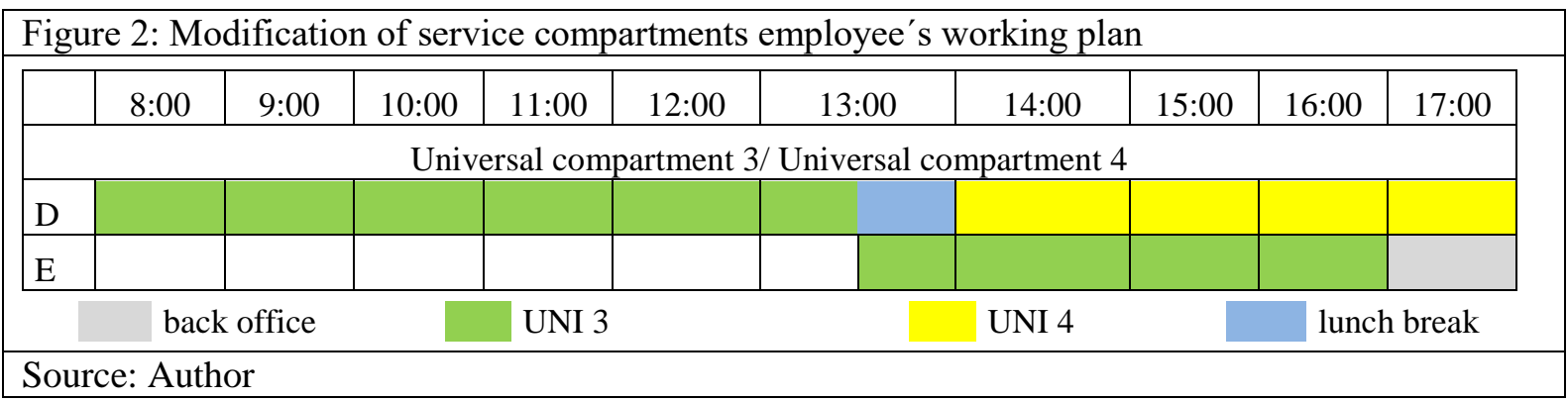

In such a case, the employer would dismiss the employee due to redundancy and reduce the number of employees to ensure the efficiency of the operations. However, such an option would mean additional costs of severance pays. The severance pay is based on the employee's average monthly earnings plus the number of years they have worked. An employer may also offer an employee another place of employment. If an employee refuses the offer, they are then terminated and lose their opportunity for a severance payment. If the post office chose to transfer the employee to another workplace, only the costs associated with a staffing agent would arise. In this case, the amount of the cost savings would relate to reductions in wage costs (net wage plus employer contributions).

\section{Conclusion}

The queuing theory is a mathematical discipline that deals with processes affected by various parameters. The aim of the queuing theory is to ensure that the service lines are sufficiently exploited, while limiting the creation of lengthy queues. Improving the efficiency of some part of the system usually leads to cost savings. In this paper, the results show that the queuing theory is a powerful optimization tool that would help save the labor costs of a post office in Bytca. The optimization proposal itself was preceded by a detailed analysis of the system, which included measuring customer inflow and service times. It also included verifying the probable distribution of the system's input parameters mentioned above and selecting the most fitting model of the queuing system. Several simulation scenarios helped examine the characteristics of the system and led to optimizing the number of service compartments available at time intervals to service the intensity of incoming customers. At the time of the study, six service compartments were available to the customer for the entire opening time of the post office. It is proposed that five service compartments operate in the time interval from 8:00 to 14:00 hours, six service compartments during 14:00 to 16:00 hours, and only four from 16:00 to 17:00 hours. The second part of the analysis concerned the working schedule of post office compartments employees. At the time of the study, there were nine compartments employees of post office who alternated between two service compartments. The study's optimization proposal modifies the work schedule of compartment employees, specifically employees serving Universal Compartments 3 and, 4. By reducing the number of service compartments in most time intervals, the serving of the compartments could be managed by two employees. The third existing employee could be offered a position at another post office in the neighborhood. In this way, the Bytca post office would avoid the costs associated with severance payments.

\section{Acknowledgements}

VEGA 1/0721/18 Research on the Economic Impact of Visual Smog in Transport Using Neuroscience Methods

\section{References}

Yang, S., Yang, X. (2014). The Application of the Queuing Theory in the Traffic Flow of Intersection. In: International Journal of Mathematical, Computational Sciences. 8, 986-989. Retrieved from http://waset.org/publications/9999252/theapplication-of-the-queuing-theory-in-the-traffic-flow-of-intersection.

Achimsky,K.: Simulačné modely vo výuke a ich využitie pri riešení problémov prepravy pošty a PNS. In: Celoštátny vedecký seminár F-PEDaS VŠDS, Žilina, 3.-4. februára 1988, str. 115-117.

Achimsky,K.: Príručka pre užívatel’ov. In: Optimalizácia oblastnej poštovej prepravnej siete. VÚ KS VŠDS, Žilina, 1985, 39 strán.

Krpan, L., Marsanic, R., Milkovic, M. (2017). A model of the dimensioning of the number of service places at parking lot entrances by using the queuing theory. In: Technicki Vjesnik-Technical Gazette. 24, 231-238.

Achimsky,K.: Simulácia činnosti poštovej priehradky.In: Zborník vydaný na počest životného jubilea Prof. RNDr. Michala Haranta, Žilina, Február 1990, str. 127-133. 
Hu, X.,Barnes, S., Golden, B. (2018), Applying queueing theory to the study of emergency department operations: a survey and discussion of comparable simulation studies. In: International transactions in operational research. 25, 4-59. Retrieved from http://onlinelibrary.wiley.com/doi/10.1111/itor.12400/abstract

Bahadori, M ,m Mohammadnejhad, SM., Ravangard, R., Teymourzadeh, E. (2014). Using Queuing Theory and Simulation Model to Optimize Hospital Pharmacy Performance. In: Iranian red crescent medical Journal. 16, 3. Retrieved from http://cdn.neoscriber.org/cdn/serve/313ea/7559b1e1b853f713f4b7bad8fc478997f49b8699/16255-pdf.pdf

Knessl, C., van Leeuwaarden, JSH. (2015). Transient Analysis of the Erland A model. In: Mathematical methods of operations research. 82, 143-173. Retrieved from https://link.springer.com/content/pdf/10.1007\%2Fs00186-015-0498-9.pdf

Brezavscek, A., Baggia A. (2014). Optimization of a call Centre Performance Using the Stochastic Queuing Models. In: Business Systems Research. 5, 6-18. Retrieved from https://www.degruyter.com/downloadpdf/j/bsrj.2014.5.issue-3/bsrj2014-0016/bsrj-2014-0016.pdf

Marsanic, R., Zenzerović, Z., Mrnjavac, E. (2015). Application of the Queuing Theory in the Planning of Optimal Number of Servers In Closed Parking Systems. 24, 26-43. Retrieved from http://www.tandfonline.com/doi/pdf/10.1080/1331677X.2011.11517453?needAccess=true\&

Reiner, K., Frank, H., Kremenova, I., Madlenak, R. (2016). Modelling of technological reliability in traffic logistic networks in urban areas. In: MATEC web of conferences. 44, Retrieved from https://www.matecconferences.org/articles/matecconf/pdf/2016/07/matecconf_iceice2016_01046.pdf

Fabus, J., Kremenová, I. (2013). Evolution of Post in region of Žilina. In: International Journal of Science and Engineering Applications (IJSEA). 2. Retrieved from http://www.ijsea.com/archive/volume2/issue2/IJSEA02021002.pdf

Kendall, D. G. (1953). "Stochastic Processes Occurring in the Theory of Queues and their Analysis by the Method of the Imbedded Markov Chain". The Annals of Mathematical Statistics. 24 (3): 338.

Pesko, $\breve{S}$. (2015). Elementárne systémy hromadnej obsluhy. Retrieved from https://frcatel.fri.uniza.sk/users/pesko/THO/sTeoriaHromadnejObsluhy_3.pdf

Husek R., Lauber, J. (1987). Simulačné modely. Praha: ALFA.

Liao, G., Chiang W. 2013). Optimal Scheduling Problem for Taiwan's Post Office Counters and Manpower. Industrail Engineering and Engineering Management. Retrieved from https://ieeexplore.ieee.org/document/6962385/ 